\title{
Higher Learning Institutions Students' Perspective on Public Smoking Ban Legislation
}

Nalini Arumugam, Geraldine De Mello, Mohammad Nor Afandi Ibrahim, Mohamad Idham Hj Md Razak, Helmy Fadlisham Abu Hasan

To Link this Article: http://dx.doi.org/10.6007/IJARBSS/v11-i11/11016 DOI:10.6007/IJARBSS/v11-i11/11016

Received: 19 September 2021, Revised: 20 October 2021, Accepted: 01 November 2021

Published Online: 18 November 2021

In-Text Citation: (Arumugam et al., 2021)

To Cite this Article: Arumugam, N., Mello, G. De, Ibrahim, M. N. A., Razak, M. I. H. M., \& Hasan, H. F. A. (2021). Higher Learning Institutions Students' Perspective on Public Smoking Ban Legislation. International Journal of Academic Research in Business and Social Sciences, 11(11), 1018-1024.

Copyright: (C) 2021 The Author(s)

Published by Human Resource Management Academic Research Society (www.hrmars.com)

This article is published under the Creative Commons Attribution (CC BY 4.0) license. Anyone may reproduce, distribute, translate and create derivative works of this article (for both commercial and non-commercial purposes), subject to full attribution to the original publication and authors. The full terms of this license may be seen

at: http://creativecommons.org/licences/by/4.0/legalcode

Vol. 11, No. 11, 2021, Pg. $1018-1024$

Full Terms \& Conditions of access and use can be found at http://hrmars.com/index.php/pages/detail/publication-ethics 


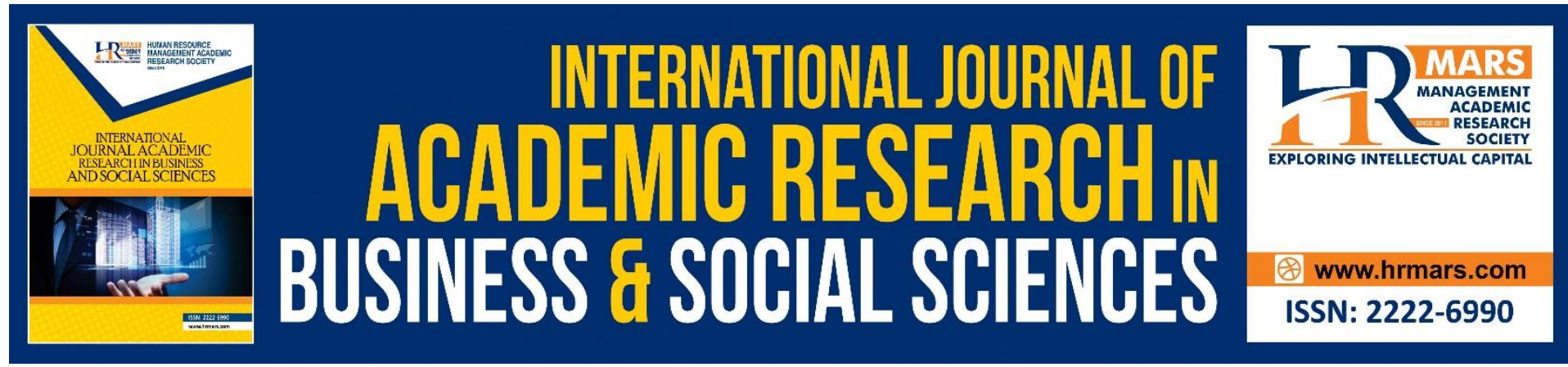

\title{
Higher Learning Institutions Students' Perspective on Public Smoking Ban Legislation
}

\author{
Nalini Arumugam, Geraldine De Mello, Mohammad Nor Afandi \\ Ibrahim, Mohamad Idham Hj Md Razak, Helmy Fadlisham Abu \\ Hasan \\ Universiti Teknologi MARA Shah Alam \\ Email: nalini@uitm.edu.my, geraldine@uitm.edu.my, afandi664@uitm.edu.my, \\ iedham@uitm.edu.my, helmyfadlisham@uitm.edu.my
}

\begin{abstract}
Tobacco smoking continues to be a major cause of death and disability around the world and is also a main provider towards our health inequalities. The legislation of banning smoking in public can help in improving smokers' health. Hence, this study aims to identify the students' perceptions if the legislation of public smoking at higher learning institutions has changed smokers' attitude and habit specifically in Malaysia. This study adopted a quantitative research approach to elicit data. An online survey using Google form application is used to distribute the questionnaires. A total of 106 undergraduates participated in this study. Data were analysed via SPSS software and descriptive analysis. The findings indicated that the smoking ban has changed the undergraduate smokers' attitude. The majority of the respondents preferred the legislation on the smoking ban to be implemented to all and were against smoking at public places as this will educate all smokers especially students to reduce or quit the smoking culture. The findings also revealed that majority of the undergraduates are aware that smoking has a negative impact on the innocent second-hand smokers, as it will deteriorate their health and may lead to fatal disease. Many respondents shared that they are seriously thinking of quitting smoking, however, some are not successful as they perceive smoking to be a form of relaxation and a way to reduce their stress. This study concludes with recommendations for further studies to be carried out to encourage the students to give up smoking totally.
\end{abstract}

Keywords: Smoking, Legislation, Ban, Public, Health

\section{Introduction}

The legislation of banning smoking in public can help in improving the health of smokers'. The smoking ban at all restaurants and other eateries, including open- air hawker stalls, came into effect in Malaysia on Jan 12019 (Buchanan, 2019). Norshidi (2019) explains that smoking is banned at any "eating place," which is defined as any premises whether inside or outside a building, where food is prepared, served or sold. The law requiring smokers in Malaysia to light up at least three meters away from open-air eateries has sparked a national debate, with many businesses complaining of fewer customers after this law. The law was intended to 
reduce the harm caused by second-hand smoke. Additionally, tobacco smoking remains a major cause of death and disability around the world, as well as being a major contributor to health inequalities. Therefore, with the implementation of the legislation of banning smoking in public, it is hoped that smoking will cease to be the main contributor to the many health hazards.

\section{Legislation on Smoking in Public}

Smoking cigarette is a hard habit to break because tobacco contains the very addictive chemical nicotine (Elana Pearl Ben - Joseph, 2019). Moreover, smoking can cause lung disease by damaging your lungs airways and the small air sacs found on your lungs around six million people die from long-term exposure to first- or second-hand smoke annually (WHO,2015). Meanwhile, vape or electronic cigarette is a first-generation that resembles tobacco cigarette.

\section{Impact of Public Smoking}

Based on the online survey given by Malaysia's New Straits Times newspaper, there are $80 \%$ of more than 25,000 respondents who thought that the policy of requiring smokers in Malaysia to light up at least three metres away from the open-air eateries should go even further, supporting that hotels and launderettes should also be listed as smoke-free zones. Abdul Rahman (2019) said that the policy is an effort to protect the masses from the secondhand smoke in public areas. He also stated that the smokers seeked help to quit smoking by going through some therapies and health-care consultations. However, the support for these programmes are low as smokers who are attempting to quit are at high risk of relapsing. They need continuous abstinence from cigarettes for at least 6 months and the smokers' themselves have to be given good support in the first week of the program itself (Clinical practice guidelines). Tauras (2015) stated the use of cigarette excise taxes to generate additional revenues to compensate for fiscal shortages associated with the recent downturn in the economy.

\section{Problem Statement}

The World Health Organization (WHO) (2012) concluded that environmental (secondhand) tobacco smoke causes lung cancer among non-smokers. Norshidi (2019) said the government banned smoking in air-conditioned restaurants, schools, petrol stations, government premises and on public transport. Yet more than 10 years on, that rule has been largely ignored. Now, the new law gives authorities the power to fine smokers up to RM10,000 if they flout it. However, some say the number of smokers in the United Kingdom has also decreased, with less than 15 percent of people smoking in 2019, compared to 22 percent in 2006. Whether this is due to the smoking ban is debatable. However, it is likely that the ban has contributed to the decline in the number of smokers. As of $2012,79 \%$ of Parties reported strengthening their existing legislation or adopting new tobacco control legislation after ratifying the Convention. Additionally, over half of the Parties to the WHO FCTC reported having developed and implemented comprehensive tobacco control strategies, plans and programs as required in Article 5.1 of the Convention. Consequently, not much has been done to study this impact of legislation ban on public smoking in higher learning institutions. Hence, this study aims to find out whether public smoking ban has brought any changes among students' attitude in smoking in the campus. 


\section{Research Questions}

i. Why we need to legislate public smoking ban?

ii. How has the smoking ban changed smokers' attitude?

\section{Methodology}

This study employed the quantitative method to collect data. This study had respondents from Universiti Teknologi Mara, Universiti Malaya, Universiti Kebangsaan Malaysia, Taylors University and Tunku Abdul Rahman University. A total of 106 undergraduates responded, 50 males and 56 females. All of them were above 18 years old. A set of questionnaires was distributed via google link from 11 October 2020 until 3 November 2020. Data were analyzed using descriptive analysis.

\section{Results and Discussion}

\begin{tabular}{|l|l|c|c|c|}
\hline No. & \multicolumn{1}{|c|}{$\begin{array}{c}\text { Disagree } \\
\%\end{array}$} & $\begin{array}{c}\text { Agree } \\
\%\end{array}$ & MEAN \\
\hline 1. & $\begin{array}{l}\text { It is good that the government legislate public } \\
\text { smoking ban. }\end{array}$ & 14.0 & 73.8 & 3.90 \\
\hline 2. & I believe that men smoke more than women. & 13.0 & 67.3 & 3.86 \\
\hline 3. & $\begin{array}{l}\text { I support with the fine who smoke in the } \\
\text { prohibited areas. }\end{array}$ & 16.0 & 66.0 & 3.81 \\
\hline 4. & $\begin{array}{l}\text { I support that the new legislation on public } \\
\text { smoking can improve the education among } \\
\text { the students to stop smoking. }\end{array}$ & 13.0 & 71.0 & 3.81 \\
\hline 5. & $\begin{array}{l}\text { I agree that the new legislation should be } \\
\text { sufficient to reduce this smoking cultured. }\end{array}$ & 13.0 & 65.5 & 3.72 \\
\hline 6. & $\begin{array}{l}\text { I support that the banning of smoking in } \\
\text { public can reduce the number of smokers. }\end{array}$ & 23.4 & 62.6 & 3.60 \\
\hline 7. & $\begin{array}{l}\text { I believe that the designated smoking areas }(3 \\
\text { metres) can be accepted by the smokers. }\end{array}$ & 16.8 & 58.9 & 3.50 \\
\hline 8. & $\begin{array}{l}\text { It is difficult to refrain from smoking in places } \\
\text { where it is forbidden. }\end{array}$ & 26.2 & 42.0 & 3.15 \\
\hline 9. & $\begin{array}{l}\text { Parents never talk to me about the dangers of } \\
\text { smoking. }\end{array}$ & 73.8 & 12.1 & 2.05 \\
\hline 10. & As a smoker, it is alright to smoke at public. & 76.6 & 11.2 & 1.89 \\
\hline
\end{tabular}

Table 1: Legislating public smoking ban.

Table 1 shows the legislate public smoking ban. For question 1, 73.8\% of respondents agreed with the statement that it is good for the government to legislate public smoking ban while $14 \%$ disagree with the mean of 3.90 which is the highest. Sapakir (2015) stated that almost all persistent smokers light up at public areas, which does not show a good attitude. For question 2,67.3\% of respondents agreed that they believe men smoke more than women and $13.0 \%$ are not agreed. The mean for this question is 3.86 . Next is $66 \%$ agreed that smoker who smokes at the prohibited areas should be fine and only $16 \%$ disagree with the mean of 3.81. The mean for question 4 is also 3.81 where we asked them whether they support the 
new legislation on public smoking ban can improve the education among the students to stop smoking. $71 \%$ agreed with the statement and $13 \%$ disagree with it.

For the fifth statement, $65.5 \%$ respondents agree that the new legislation should be enough to reduce this smoking cultured and $13 \%$ disagree with the mean of 3.72 . $62.6 \%$ of respondents support that the banning of smoking in public can reduce the number of smokers and $23,4 \%$ did not agree and the mean for this is 3.60. Most of the respondents $(58.9 \%)$ believe that the designated smoking areas (3metres) can be accepted by the smokers and $16.8 \%$ disagree. Buchanan (2019) said that 2018 amendments, the regulations prohibited smoking only in air-conditioned, which until amendments were made in 2017, we able to have a designated area. The mean for this question is 3.50 . Furthermore $42 \%$ agreed that is difficult to refrain from smoking in places where it is forbidden and $26.2 \%$ disagree with the mean 3.15. 73.8\% disagree that parents never talk to them about the dangers of smoking and $12.1 \%$ disagree with the mean of 2.05. The last statement is as a smoker, is it okay to smoke in public, $76.6 \%$ disagree and 11.2 agree the mean for this statement is the lowest which is 1.89 .

\begin{tabular}{|l|l|c|c|c|}
\hline No. & \multicolumn{1}{|c|}{$\begin{array}{c}\text { Disagree } \\
\%\end{array}$} & $\begin{array}{c}\text { Agree } \\
\%\end{array}$ & MEAN \\
\hline 1. & $\begin{array}{l}\text { I aware that smoking from cigarettes will } \\
\text { affect the non-smoker. }\end{array}$ & 3.7 & 86.9 & 4.42 \\
\hline 2. & $\begin{array}{l}\text { Smoking will increase the disease, stroke } \\
\text { and lung cancer. }\end{array}$ & 7.6 & 86.8 & 4.40 \\
\hline 3. & $\begin{array}{l}\text { I aware of the long-term effect of smoking } \\
\text { to my health. }\end{array}$ & 3.8 & 85.8 & 4.34 \\
\hline 4. & $\begin{array}{l}\text { I aware with the ingredients in the } \\
\text { cigarettes that can kill the brain cells } \\
\text { which can lead to the brain damage. }\end{array}$ & 5.7 & 80.2 & 4.29 \\
\hline 5. & $\begin{array}{l}\text { I am aware of the effects of smoking to my } \\
\text { health. }\end{array}$ & 6.5 & 84.1 & 4.28 \\
\hline 6. & $\begin{array}{l}\text { Smoking cigarettes could be harmful to my } \\
\text { health. }\end{array}$ & 10.4 & 77.7 & 4.14 \\
\hline 7. & $\begin{array}{l}\text { I am seriously thinking of quitting } \\
\text { smoking. }\end{array}$ & 4.7 & 63.2 & 3.91 \\
\hline 8. & $\begin{array}{l}\text { When I started smoking, I will crave more } \\
\text { cigarettes. }\end{array}$ & 32.7 & 34.5 & 2.95 \\
\hline 9. & When I smoke, I feel relaxed. & 51.4 & 22.4 & 2.49 \\
\hline 10. & When I smoke, I can decrease your stress. & 54.2 & 22.4 & 2.43 \\
\hline
\end{tabular}

Table 2: Smoker's attitude after the smoking ban.

Table 2 shows the smokers' attitude after the smoking ban. The first question shows that $86.9 \%$ of the respondents were aware that smoking from cigarettes will affect the nonsmoker and $3.7 \%$ are not aware. The mean for this question is 4.42 which is the highest for this part. Next, $86.8 \%$ respondents agreed that smoking will increase the disease, stroke and lung cancer and $7.6 \%$ are disagree with the mean of $4.40 .85 .8 \%$ of the respondents aware the long-term effect of smoking to their health and only $3.8 \%$ disagree with the mean of 4.34 . 
For the fourth question, $5.7 \%$ of respondents are not aware with the ingredients in the cigarettes that can kill the brain cells which can lead to the brain damage and $80.2 \%$ are conversely. The mean for this question is $4.9 \%$. Lee (2015) stressed that despite the harmful ingredients and eye-opening illustrations about the risks of smoking being put in cigarette packs, the smokers concern over the dangers are still low.

$84.1 \%$ of the respondents aware of the effects of smoking to their health and $6.5 \%$ are not aware with it and the mean for this is $4.28 .77 .7 \%$ agreed that smoking could be harmful to them and $10.4 \%$ are not. The mean for this 4.14. Trevallion (2017) explained that smoking can increase an adult smoker's risk of lung cancer and heart disease by a quarter, and of stroke $30 \%$. For the question number 7 , most of the respondents seriously thinking of quitting smoking and $4.7 \%$ are not serious. The mean for this is 3.91. Cheseeman (2017) said that directly after legislation, more people were trying to quit smoking and more people succeeded because it is much easier to avoid those situations. Furthermore, $34.5 \%$ of the respondents agree that when they started smoking, they will crave for more cigarettes. $32.7 \%$ are disagree with this and the mean for this is $2.95 .55 .4 \%$ are not agree with the statement that when they smoke, they feel relaxed and $22.4 \%$ agree with it. The mean for this question is 2.49. The last question is when they smoke, they can decrease their stress. $22.4 \%$ respondents agree and $54.2 \%$ disagree with the mean of 2.43 . Norshidi (2019) stated that one of the respondents agreed that smoking can reduce stress and to stop that, it will take some time.

The legislation on the smoking ban must be implemented to public. Hence, we need to support the legislation implemented by the government. As for smokers, smoking at eateries 3 meters away from that place does not disturb other customers. Furthermore, most of respondents also support the new legislation on public smoking and believe that public smoking ban is enough to reduce the number of smokers.

In short, the smoking ban has changed smokers' attitude by limiting their wants to smoke and improve their health. Based on the results, the majority of the respondents agreed that smoking cigarettes could be harmful to their health as they can suffer from lung cancer, stroke and other diseases. Additionally, the smoke from cigarettes also affect secondhand-smokers such as children and pregnant women. The smoke from the ingredients of cigarettes could be more dangerous and causes death, disease and disability.

\section{Conclusion}

From the data collected most of the respondents agreed with the implementation of the legislation of the public smoking ban. They are aware that there are many negative impacts due to smoking and this might be the right time to change the smoking culture. The respondents are also alert with the fine by the authorities for not smoking in the designated area which is 3 metres away from the eateries. Some of them also disagree with the rule. They think it is okay to smoke in public if they are not disturbing others. They believe that the designated smoking areas which is 3 meters can be accepted by the smokers. Most of the respondents agreed that the smoking ban has changed smokers' attitude. They are aware of the effects of smoking to their health in the long run and the many negative effects from smoking for both the smokers and second-hand smokers. Additionally, it was found that most parents never talk about the dangers of smoking to their children as they feel that it is not 
important. They responded only when their children brought it up. However, this area on parental communication with their children about the topic of smoking needs more research attention.

\section{Recommendations}

The first recommendation is to have more designated areas for smoking. This is to help the smokers to smoke freely when they are in public without disturbing the others. In this way, the number of second-hand smokers can be reduced. The government and non-government organizations should undertake strong efforts to provide awareness to the smokers that the attitude of smoking in public will give bad effects to the non-smoker. This is supported by the fact that shows the non-smoker gains more side effects rather than the smokers themselves. The last recommendation is the authority should do more patrolling around public area and they also can increase the amount of fine and the punishment to the smokers who do not obey the regulations.

\section{References}

Abdul Rahman. (2019). What ban? Many still ignoring smoking ban | The Star https://www.thestar.com.my > nation > 2019/01/01

Buchanan, K. (2019-01-17). "Malaysia: Ban on Smoking in All Eateries Comes into Effect / Global Legal Monitor". www.loc.gov. Retrieved 2020-03-31.

Ben-Joseph, E. P. (2019). Secohdhand Smoke. Reviewed by Elana Pearl Ben-Joseph, MD. https://www.wakehealth.edu/KH/clinical/lic415/en/parents/secondhand-smoke_html

Norshidi, S. (2019). New smoking law lights up Malaysia's fight against tobacco, but still a long road ahead. China Fintech Report, Retrieved from https://www.scmp.com/lifestyle/health-wellness/article/3015373/new-smoking-lawlights-malaysias-fight-against-tobacco

Tauras. (2019). The Impact of Tax and Price on the Demand for Tobacco Products. https://cancercontrol.cancer.gov > default >

WHO, W. H. O. (2012). WHO _ Why is smoking an issue for non-smokers. World Health Organization. WHO Report on the Global Tobacco Epidemic, 2011: Warning About the Dangers of 